\title{
PERTUKARAN INFORMASI PADA MASYARAKAT ADAT KAMPUNG NAGA
}

\author{
Sukaesih ; Nurmaya Prahatmaja ; Asep Saeful Rohman \\ Program Studi Ilmu Perpustakaan Universitas Padjadjaran \\ sukaesihcicih09@yahoo.co.id ; nurmayaprahatmaja@yahoo.com ; \\ asep.saefulr@gmail.com
}

\begin{abstract}
ABSTRAK
Penelitian ini bertujuan untuk mengetahui berbagai faktor yang berpengaruh dalam pertukaran informasi di kalangan masyarakat adat Kampung Naga. Lokasi penelitian di Kampung Naga, Kecamatan Salawu, Kabupaten Tasikmalaya, Provinsi Jawa Barat. Metode yang digunakan dalam penelitian ini adalah metode deskriptif dengan pendekatan kualitatif. Populasi dalam penelitian ini adalah masyarakat Kampung Naga di Kecamatan Salawu Kabupaten Tasikmalaya dengan teknik pengambilan sampling menggunakan teknik purposive (purposive sampling). Pengumpulan data dilakukan melalui wawancara, observasi dan studi kepustakaan. Hasil penelitian menunjukkan bahwa terdapat karakteristik individu yang meliputi aspek pendidikan, jenis kelamin, serta agama yang berpengaruh terhadap pola pertukaran informasi pada masyarakat disana. Sedangkan faktor lainnya yakni karakteristik sosial yang berupa norma-norma, masih dipegang erat oleh masyarakat dan turut memperlancar pola pertukaran informasi pada masyarakat adat Kampung Naga.

Kata Kunci : Karakteristik Individu, Karakteristik Sosial, Pola Pertukaran Informasi, Masyarakat Kampung Naga
\end{abstract}

\section{PENDAHULUAN}

Dalam sejarah kehidupan manusia telah lama diakui bahwa informasi merupakan bagian yang penting bahkan seringkali menentukan nasib seseorang. Berkaitan dengan hal ini, Hammer dalam Hanafi (1999) menyebutkan bahwa informasi saat ini diakui telah menjadi komoditi-komoditi yang dapat dijual, diberikan, di-copy, diciptakan, disalahgunakan, di-distorsi dan bahkan dicuri.

Berbicara tentang informasi, tidak seorangpun yang tidak membutuhkan informasi, apapun jenis pekerjaan dan status mereka di masyarakat. Adapun pengertian informasi dalam konteks komunikasi adalah suatu isi pesan yang berlangsung dalam proses komunikasi. Komunikasi merupakan bagian yang integral dari kehidupan manusia, karena manusia dalam kesehariannya tidak dapat lepas dari aktifitas komunikasi. Manusia tanpa berkomunikasi tidak akan dapat melaksanakan aktifitasnya, karena sesungguhnya setiap perilakunya adalah komunikasi. Komunikasi juga terjadi setiap saat dan berlangsung dimana saja. Dengan kata lain manusia sepanjang hidupnya selalu berkomunikasi dengan orang lain. 
Berbicara tentang komunikasi dapat diartikan dalam berbagai pengertian tergantung dari konteks yang sedang dipergunakan. Komunikasi dapat diartikan sebagai kegiatan saling tukar menukar informasi dari satu orang kepada orang lain atau antara dua orang atau lebih. Dengan komunikasi kita dapat menyalurkan ide, gagasan, pendapat atau perasaan kepada orang lain baik melalui bahasa (verbal) maupun bukan bahasa (nonverbal). Sedangkan menurut Laswell sebagaimana dikutip oleh Effendy (1993), mengartikan komunikasi sebagai suatu proses penyampaian pesan oleh komunikator kepada komunikan melalui media yang menimbulkan efek. Komunikasi merupakan hal yang penting dalam berinteraksi baik secara perorangan maupun dalam suatu lembaga atau masyarakat. Mencermati tentang kegiatan komunikasi merupakan hal yang sangat menarik seperti halnya dalam kehidupan masyarakat sehari-hari sebagaimana yang terlihat dalam kehidupan masyarakat Kampung Naga.

Masyarakat Kampung Naga adalah merupakan sebuah kelompok masyarakat yang tinggal terpencil dari kelompok masyarakat lainnya. Kelompok masyarakat ini sebenarnya bukanlah masyarakat terpencil, namun masyarakat yang mencoba memisahkan dari kehidupan masyarakat yang ada di sekitarnya. Kelompok masyarakat ini berada di wilayah Kecamatan Salawu Kabupaten Tasikmalaya Provinsi Jawa Barat. Dalam masyarakat Kampung Naga, segala adat dan istiadat nenek moyang atau leluhurnya nampak masih kuat dipertahankan. Hal ini nampak terlihat dalam kehidupan sehari-hari seperti dalam tata aturan kehidupannya, bentuk rumah, cara bertani/bercocok tanam, kegiatan berkomunikasi diantara mereka, serta dalam cara memandang dan memperlakukan alam dan lingkungan sekitarnya.

Sebagaimana umumnya dalam suatu masyarakat akan terjadi interaksi antara satu dengan lainnya. Dengan adanya interaksi ini maka akan terjadi komunikasi dan pertukaran informasi diantara anggota masyarakat. Berkaitan dengan hal tersebut, penulis tertarik untuk mengkaji tentang aspek karakteristik individu yang meliputi pendidikan, jenis kelamin, agama, dan status sosial serta karakteristik sosial seperti norma-norma sosial yang ada pada masyarakat Kampung Naga terhadap pola pertukaran informasi di kalangan masyarakat tersebut.

Setiap orang yang melakukan komunikasi setidaknya berusaha untuk melakukannya yang terbaik, sehingga kesuksesan seseorang dalam berkomunikasi dapat menentukan kualitas hidupnya. Kesuksesan komunikasi terjadi ketika komunikasi dikatakan berlangsung efektif. Adapun mengenai komunikasi efektif jika 
meminjam pendapat Tubbs dan Moss (1996) setidaknya ditunjukkan oleh lima hal yaitu, adanya pengertian, kesenangan, pengaruh pada sikap, hubungan baik, serta tindakan yaitu komunikasi. Namun demikian dalam pelaksanaannya kerapkali dalam berkomunikasi menghadapi banyak hambatan, biasanya hambatan komunikasi terjadi karena adanya perbedaan bahasa yang digunakan, beragam pemaknaan terhadap pesan yang sama serta efek yang ditimbulkan dari situasi dan kondisi psikologis individu.

Dalam berbagai bentuk, komunikasi selalu mengambil tempat dari kehidupan manusia, tidak terkecuali dengan kehidupan masyarakat yang ada di daerah pedesaan yang terpencil seperti masyarakat Kampung Naga pun tidak terlepas dengan peristiwa-peristiwa komunikasi yang berlangsung. Dengan adanya interaksi dan komunikasi antara anggota masyarakat maka akan terjadi pertukaran informasi.

Berangkat dari uraian rumusan tersebut diatas, maka rumusan masalah penelitian yang telah dilaksanakan yakni : "Bagaimana faktor karakteristik individu dan karakteristik sosial berpengaruh terhadap pola pertukaran informasi di kalangan masyarakat Kampung Naga?”. Adapun Manfaat dari penelitian ini secara teoritis kiranya dapat memberikan sumbangsih berupa pengalaman ilmiah dalam mengkaji tentang teori-teori komunikasi melalui sebuah penelitian. Sedangkan secara praktis, diharapkan dapat memberikan masukan bagi pihak terkait dengan masalah ini khususnya Pemerintah Daerah Kabupaten Tasikmalaya dalam melakukan pengembangan wilayah Kampung Naga sebagai daerah kunjungan wisata.

\section{PEMBAHASAN}

Pada beberapa penelitian terdahulu, terdapat beberapa peneliti yang telah mengkaji berbagai fenomena yang terdapat di Kampung Adat, Kabupaten Tasikmalaya. Beberapa penelitian tersebut diantaranya yakni tentang: (a) Pemimpin Adat dan Kosmologi Waktu, yang ditulis oleh H. Sukriadi Sambas pada tahun 1998 sebagai tesis untuk memperoleh gelar Magister Sains pada Program Pendidikan Magister, Pascasarjana, Universitas Padjadjaran; (b) Pantangan Sebagai Pengendalian Sosial pada Masyarakat Kampung Naga Desa Neglasari Kecamatan Saluwu Kabupaten Tasikmalaya, yang ditulis oleh Dadang Rohana pada tahun 2001 yang diajukan untuk menempuh ujian sidang sarjana pada Program Studi Antropologi, Fakultas Ilmu Sosial dan Ilmu Politik, Universitas Padjadjaran; serta (c) Pemaknaan Tradisi Lisan dan Tulisan Pada Masyarakat Kampung Naga, yang 
ditulis oleh Dra. Siti Maryam pada tahun 2006 sebagai tesis untuk memperoleh gelar Magister Sains Program Pendidikan Magister Ilmu Sosial, BKU Ilmu Informasi dan Perpustakaan, di Universitas Padjadjaran.

Penelitian yang pertama disebutkan diatas menjelaskan bahwa pemimpin adat (Kuncen) mengkomunikasikan pandangan kosmologi tentang waktu yang mereka miliki secara bahasa tutur (lisan) serta cara penyampaian pesannya melalui komunikasi antar persona diadik, antar persona triadik, dan komunikas kelompok kepada anggota masyarakat Kampung Naga dengan tujuan untuk mempertahankan adat istiadat secara turun temurun. Substansi pandangan kosmologi waktu sebagai pesan komunikasi yang dimiliki oleh pemimpin adat terdapat dua puluh lima macam, sebagai waktu metris atau nomos yang dapat dikategorikan menjadi tujuh kategori yaitu: (1) nama, waktu, dan makna waktu; (2) waktu uga (ramalan); (3) makna khusus dalam waktu; (4) waktu nahas; (5) norma waktu khusus untuk mencari nafkah; (6) waktu sakral khusus untuk upacara adat; (7) kala dalam waktu.

Sedangkan penelitian yang terakhir yang dilakukan oleh Dra. Siti Maryam menjelaskan bahwa pimpinan adat mengkomunikasikan pikukuh secara lisan dan tulisan melalui sasuru (diadik), dua suru (triadik), dan sajuru. Kesimpulan dari penelitian ini adalah bahwa model komunikasi seperti tersebut diatas ternyata sangat efektif bagi perilaku masyarakat Kampung Naga dalam menjalankan kehidupannya sehari-hari.

Berdasarkan beberapa penelitian tersebut diatas, penulis tertarik untuk meneliti tentang karakteristik individu dan karakteristik sosial Masyarakat Kampung Naga dan kaitannya dengan pola pertukaran informasi.

\section{Karakteristik Individu}

Aspek karakteristik individu yang dibahas dalam penelitian ini meliputi : pendidikan, jenis kelamin, agama, status sosial. Penjelasan dalam bagian ini akan difokuskan pada pembahasan mengenai agama dan status sosial. Kedudukan (status) dan peranan (role) merupakan unsur-unsur baku dalam sistem lapisan masyarakat, dan mempunyai arti penting bagi sistem sosial. Yang diartikan sebagai sistem sosial adalah pola-pola yang mengatur hubungan timbal-balik antar individu dalam masyarakat dan antar individu dengan masyarakatnya, dan tingkah laku individuindividu tersebut (Linton dalam Soekanto, 2002:239). 
Kedudukan diartikan sebagai tempat atau posisi seseorang dalam suatu kelompok sosial. Kedudukan sosial artinya adalah tempat seseorang secara umum dalam masyarakatnya sehubungan dengan orang-orang lain, dalam arti lingkungan pergaulannya, prestisenya dan hak-hak serta kewajiban-kewajibannya. Menurut Linton dalam Soekanto (2002:239), secara abstrak, kedudukan berarti tempat seseorang dalam suatu pola tertentu. Dijelaskan lebih lanjut, dengan demikian, seseorang dikatakan memiliki beberapa kedudukan, oleh karena seseorang biasanya ikut serta dalam berbagai pola kehidupan. Pengertian tersebut menunjukkan tempatnya sehubungan dengan kerangka masyarakat secara menyeluruh.

Masyarakat pada umumnya mengembangkan dua macam kedudukan, yaitu : (a) ascribed-status, yaitu kedudukan seseorang dalam masyarakat tanpa memperhatikan perbedaan-perbedaan rohaniah dan kemampuan. Kedudukan ini diperoleh karena kelahiran, misalnya kedudukan anak seorang bangsawan adalah bangsawan pula; serta (b) achieved-status, yakni kedudukan yang dicapai oleh seseorang dengan usaha-usaha yang disengaja. Kedudukan ini tidak diperoleh atas dasar kelahiran, akan tetapi bersifat terbuka bagi siapa saja tergantung dari kemampuan masing-masing dalam mengejar serta mencapai tujuan-tujuannya. Kedudukan seseorang atau kedudukan yang melekat padanya dapat terlihat pada kehidupan sehari-harinya melalui ciri-ciri tertentu yang dinamakan prestise-simbol (status-symbol).

Adapun agama juga mempunyai pengaruh besar didalam membentuk kepribadian seorang individu. Bahkan adanya berbagai mahzab didalam suatu agama, pun melahirkan pula kepribadian yang berbeda-beda di kalangan umat pemeluknya.

\section{Karakteristik Sosial}

Karakteristik sosial yang dibahas dalam penelitian ini yaitu norma-norma sosial yang ada pada masyarakat Kampung Naga. Norma-norma dalam suatu masyarakat dirumuskan agar supaya hubungan antar manusia di dalam suatu masyarakat terlaksana sebagaimana yang diharapkan. Mula-mula norma tersebut terbentuk secara tidak sengaja, namun lama-kelamaan norma tersebut dibuat secara tidak sadar. Norma-norma yang ada didalam masyarakat, mempunyai kekuatan mengikat yang berbeda-beda. Ada norma yang lemah, yang sedang sampai yang paling kuat daya ikatnya. Pada norma yang terakhir disebutkan, umumnya anggota- 
anggota masyarakat tidak berani melanggarnya. Menurut Soekanto (2002 : 200), untuk dapat membedakan kekuatan mengikat norma-norma tersebut, secara sosiologis dikenal adanya empat pengertian, yaitu : (a) Cara (usage), (b) Kebiasaan (folkways), (c)Tata kelakuan (mores), dan (d) Adat istiadat (custom).

Masing-masing pengertian di atas mempunyai dasar yang sama yaitu merupakan norma-norma kemasyarakatan yang memberikan petunjuk bagi perilaku seseorang yang hidup dalam masyarakat. Setiap pengertian diatas, memiliki kekuatan yang berbeda karena setiap tingkatan menunjuk pada kekuatan memaksa yang lebih besar supaya menaati norma.

Cara (usage) merujuk pada suatu bentuk perbuatan. Norma ini mempunyai kekuatan yang sangat lemah bila dibandingkan dengan kebiasaan (folkways). Kebiasaan merujuk pada perbuatan yang diulang-ulang dalam bentuk yang sama. Cara (usage) lebih menonjol di dalam hubungan antar individu dalam masyarakat. Suatu penyimpangan terhadapnya tidak akan mengakibatkan hukuman yang berat, akan tetapi sekedar celaan dari individu yang dihubunginya.

Kebiasaan (folkways) memiliki kekuatan mengikat yang lebih besar daripada Cara. Kebiasaan diartikan sebagai perbuatan yang diulang-ulang dalam bentuk yang sama, merupakan bukti bahwa orang banyak menyukai perbuatan tersebut. Menurut Maclver dan Page dalam Soekanto (2002: 2001), kebiasaan merupakan perilaku yang diakui dan diterima oleh masyarakat. Selanjutnya dikatakan bahwa apabila kebiasaan tersebut tidak semata-mata dianggap sebagai cara perilaku saja, akan tetapi bahkan diterima sebagai norma-norma pengatur, maka disebutkan kebiasaan tadi sebagai mores atau tata-kelakuan.

Tata-kelakuan menurut Soekanto (2002 : 201), mencerminkan sifat-sifat hidup dari kelompok manusia yang dilaksanakan sebagai alat pengawas, secara sadar maupun tidak sadar oleh masyarakat terhadap anggota-anggotanya. Tata-kelakuan disatu pihak memaksakan suatu perbuatan dan dilain pihak melarangnya sehingga secara langsung merupakan alat agar anggota masyarakat menyesuaikan perbuatanperbuatannya dengan tata-kelakuan tersebut. Lebih lanjut Soekanto menyatakan bahwa tata-kelakuan sangat penting karena memberikan batas-batas pada perilaku individu, mengidentifikasi individu dengan kelompoknya, serta menjaga solidaritas antar anggota masyarakat.

Tata kelakuan yang kekal serta kuat integrasinya dengan pola-pola perilaku masyarakat dapat meningkat kekuatan mengikatnya menjadi custom atau adat- 
istiadat. Anggota masyarakat yang melanggar adat-istiadat akan menderita sanksi yang keras yang kadang-kadang tidak secara langsung diperlakukan. Norma-norma tersebut, setelah mengalami suatu proses, pada akhirnya akan menjadi bagian tertentu dari lembaga kemasyarakatan. Proses tersebut dinamakan proses pelembagaan (institutionalization), yaitu suatu proses yang dilewati oleh suatu norma yang baru untuk menjadi bagian dari salah satu lembaga kemasyarakatan. Yang dimaksud disini adalah, sampai kemudian norma itu oleh masyarakat dikenal, diakui, dihargai, dan kemudian ditaati dalam kehidupan sehari-hari (Wiese dan Becker dalam Soekanto, 2002: 203).

\section{Pola Pertukaran Informasi}

Untuk memperoleh pengertian mengenai segi yang dinamis dari masyarakat, kita terlebih dahulu harus mempelajari pengetahuan tentang proses-proses sosial yang terdapat dalam masyarakat. Menurut Soekanto (2002: 60), proses sosial adalah cara-cara berhubungan yang dilihat apabila orang perorangan dan kelompokkelompok sosial saling bertemu dan menentukan sistem serta bentuk-bentuk hubungan tersebut atau apa yang akan terjadi apabila ada perubahan-perubahan yang menyebabkan goyahnya pola-pola kehidupan yang telah ada. Pembahasan lebih lanjut dalam penelitian ini akan dibatasi hanya pada bentuk-bentuk interaksi sosial yaitu bentuk-bentuk yang tampak apabila orang-orang perorangan atau kelompokkelompok manusia mengadakan hubungan satu sama lain terutama dengan mengetengahkan kelompok serta lapisan sosial sebagai unsur pokok struktur sosial.

Interaksi sosial adalah kunci utama dari semua kehidupan sosial, oleh karena itu tanpa interaksi sosial, tidak akan mungkin ada kehidupan bersama (Young dan Mack dalam Soekanto, 2002: 61). Lebih lanjut dikatakan, bertemunya orang perorangan secara badaniah belaka tidak akan menghasilkan pergaulan hidup dalam suatu kelompok sosial. Pergaulan hidup semacam itu baru akan terjadi apabila orangorang perorangan atau kelompok-kelompok manusia bekerja sama, saling berbicara, dan seterusnya untuk mencapai suatu tujuan bersama, mengalami persaingan, terjadi pertikaian, dan lain sebagainya. Maka dapat dikatakan bahwa interaksi sosial adalah dasar proses sosial, pengertian mana menunjuk pada hubungan-hubungan sosial yang dinamis.

Bentuk umum proses sosial adalah interaksi sosial oleh karena interaksi sosial merupakan syarat utama terjadinya aktivitas-aktivitas sosial. Menurut Gillin and 
Gillin dalam Soekanto (2002: 61), interaksi sosial merupakan hubungan-hubungan sosial yang dinamis yang menyangkut hubungan antara orang perorangan, antara kelompok-kelompok manusia, maupun antara perorangan dengan kelompok manusia. Interaksi sosial antara kelompok-kelompok manusia terjadi antara kelompok tersebut sebagai kesatuan dan biasanya tidak menyangkut pribadi anggotaanggotanya. Berlangsungnya suatu proses interaksi didasarkan pada berbagai faktor, antara lain faktor imitasi, sugesti, identifikasi, dan simpati. Faktor-faktor tersebut dapat bergerak sendiri-sendiri secara terpisah maupun dalam keadaan bergabung.

Dengan adanya interaksi dan komunikasi antara anggota masyarakat maka akan terjadi pertukaran informasi. Sedangkan mengenai informasi itu sendiri, Diao Ai Lien (1996 : 9) mengelompokkannya menjadi tiga yakni : (1) Dunia informasi, yaitu seluruh fakta, data kepercayaan, pendapat, bayangan mental dan benda-benda; (2) Informasi potensial yang obyektif, yaitu bagian dari dunia informasi yang diperlukan untuk suksesnya pencapaian tujuan pencari informasi, tidak peduli apakah pencari informasi menyadarinya atau tidak; dan (3) Informasi potensial yang subyektif, yaitu bagian dari dunia informasi yang menurut si pencari informasi berguna baginya adalah bagian dunia informasi yang ada dalam status aktif yang menggerakkan proses berpikir si pemakai informasi.

Berdasarkan pengelompokkan tersebut, maka informasi bisa baru sama sekali bagi si pemakai atau mungkin juga tidak (sudah ada di dalam benaknya). Idealnya, isi, karakteristik dan mutu informasi potensial subyektif harus sama dengan informasi potensial obyektif. Dengan kata lain pemakai informasi harus menyadari semua informasi yang dibutuhkannya. Namun demikian dalam kenyataannya tidak mudah, kecuali untuk tugas yang sangat spesifik dan sederhana.

Kemudian untuk menjelaskan tentang kebutuhan informasi, masih menurut Diao Ai Lien (1996 : 10) membagi kebutuhan informasi manusia menjadi tiga macam kebutuhan yakni : (1) Kebutuhan informasi yang obyektif, yaitu kebutuhan yang seharusnya ada kala seseorang mau mencapai tujuannya dengan sukses. Kebutuhan informasi obyektif ini menentukan ruang lingkup informasi potensial obyektif; (2) Kebutuhan informasi subyektif, yaitu kebutuhan informasi yang disadari seseorang sebagai persyaratan untuk suksesnya pencapaian tujuan. Kebutuhan jenis ini menentukan ruang lingkup informasi potensial subyektif. Namun yang sering menjadi permasalahan adalah kebutuhan informasi yang disadaripun kerapkali tidak selalu mudah untuk merumuskannya; dan (3) Kebutuhan informasi 
yang terpenuhi, yaitu kebutuhan informasi yang disadari seseorang dan terpenuhi kebutuhannya.

\section{Wilayah dan Masyarakat Kampung Naga}

Secara administratif, Kampung Naga termasuk kedalam wilayah Desa Neglasari, Kecamatan Salawu, Kabupaten Tasikmalaya, di Propinsi Jawa Barat. Kampung ini berada di jalur regional antara Kota Singaparna dan Kota Garut, dengan jarak $33 \mathrm{~km}$ dari arah barat daya Kota Singaparna atau $30 \mathrm{~km}$ dari arah timur laut Kota Garut. Sedangkan dari arah Bandung sebagai Ibu Kota Propinsi jaraknya yakni sekira $106 \mathrm{~km}$.

Adapun luas area Kampung Naga seluruhnya lebih kurang 1,5 hektar. Sebagian besar lahan yang ada digunakan untuk perumahan, pekarangan, dan kolam, selebihnya digunakan untuk lahan pertanian yakni sawah yang selalu dipanen hasilnya sebanyak satu tahun dua kali. Kampung Naga berada pada lembah yang sangat subur, dengan kemiringan sekira 45 derajat dan ketinggian sekira 488 diatas permukaan laut (Data potensi Desa Neglasari tahun 2010). Adapun batas wilayah Kampung Naga, sebelah barat dibatasi oleh Hutan Larangan (keramat) dimana di dalam hutan tersebut terdapat makam leluhur masyarakat Kampung Naga. Sebelah selatan dibatasi oleh sawah-sawah penduduk. Sebelah utara dan timur dibatasi oleh sungai Ciwulan yang sumber airnya berasal dari Gunung Cikuray di daerah Garut. Untuk menuju Kampung Naga dari arah jalan raya Garut-Singaparna harus menuruni anak tangga yang sudah ditembok (sengked dalam bahasa Sunda) sampai ketepi sungai Ciwulan dengan kemiringan 45 derajat dengan jarak sekitar 500 meter. Kemudian melalui jalan setapak menyusuri sungai Ciwulan sampai ke lokasi perkampungan.

Kampung Naga merupakan suatu perkampungan yang dihuni oleh sekelompok masyarakat yang sangat kuat dalam memegang adat istiadat peninggalan leluhurnya. Hal ini akan terlihat jelas perbedaanya apabila dibandingkan dengan masyarakat lain di luar Kampung Naga. Masyarakat Kampung Naga hidup pada suatu tatanan yang dikondisikan dalam suasana kesederhanaan, kesahajaan, keteraturan serta memiliki lingkungan kearifan tradisional yang demikian kental.

Umumnya masyarakat kampung Naga, termasuk Kuncen yakni Bapak Ade Herlin, tidak mengetahui secara pasti darimana asal muasal nenek moyang mereka berasal dan mengapa kampung mereka disebut sebagai Kampung Naga. Mereka 
berpendapat bahwa leluhur mereka berasal dari Kampung Naga sendiri. Menurut penjelasan mantan Kuncen sebelumnya yakni Bapak Ateng, sejarah atau riwayat tentang Kampung Naga ditulis pada lembaran tembaga. Namun pada tahun 1950 saat peristiwa pembakaran Kampung Naga oleh gerombolan DI/TII, naskah mengenai sejarah kampung juga ikut terbakar. Demikian juga benda-benda pusaka lainnya, seperti pakaian, tombak, keris, juga ikut musnah dilalap api.

Penuturan lain yang menceritakan sejarah/asal-usul Kampung Naga salah satu diantaranya disebutkan pada masa Kewalian Syeh Hidayatullah atau Sunan Gunung Jati, seorang muridnya yang bernama Singaparna ditugaskan untuk menyebarkan agama Islam ke sebelah barat. Kemudian ia sampai ke daerah Neglasari yang sekarang menjadi Desa Neglasari, Kecamatan Selawu, Kabupaten Tasikmalaya. Di tempat tersebut, Singaparna oleh masyarakat Kampung Naga disebut Sembah Dalem Singaparna. Suatu hari ia mendapat ilapat atau petunjuk harus melakukan semedi. Dan dalam persemediannya ia mendapat petunjuk bahwa ia harus mendalami satu tempat yang sekarang disebut sebagai daerah Kampung Naga.

Beberapa diantara nama para leluhur masyarakat Kampung Naga yang dihormati diantaranya : Pangeran Kudratullah (seorang yang dipandang sangat menguasai pengetahuan tentang Agama Islam); Raden Kagok Katalayah Nu Lencing Sang Seda Sakti (yang dipandang menguasai ilmu kewedukan atau ilmu kekebalan); Ratu Inceng Kudratullah atau disebut Eyang Mudik Batara Karang (yang dipandang menguasai ilmu kepandaian yang bersifat keduniawian atau kekayaan); serta Sunan Gunung Jati Kalijaga (yang dipandang menguasai bidang pertanian). Semua namanama leluhur Kampung Naga tersebut di atas tidak hanya dimaknakan di dalam Kampung Naga, namun tersebar di berbagai pelosok tanah Jawa.

Nenek moyang masyarakat Kampung Naga yang paling berpengaruh dan berperan bagi masyarakat Kampung Naga adalah "Sa Naga" yaitu Eyang Singaparna atau Sembah Dalem Singaparna yang disebut juga dengan Eyang Galunggung yang dimakamkan di sebelah barat Kampung Naga. Makam ini oleh masyarakat Kampung Naga dianggap sebagai makam keramat yang selalu diziarahi pada saat diadakan upacara adat bagi semua keturunannya. Namun, kapan pastinya Eyang Singaparna wafat, tidak diperoleh data yang pasti. Bahkan tidak seorang pun warga Kampung Naga yang mengetahuinya. Menurut kepercayaan yang mereka warisi secara turun temurun, nenek moyang masyarakat Kampung Naga tidak meninggal dunia, melainkan tilem (raib) tanpa meninggalkan jasad. Dan di tempat itulah 
masyarakat Kampung Naga menganggapnya sebagai makam dengan memberikan tanda atau petunjuk berupa petilasan bagi keturunan masyarakat Kampung Naga.

Menurut data yang ada di Rukun Tetangga (RT), penduduk Kampung Naga berjumlah 325 jiwa yang terdiri dari penduduk laki-laki sebanyak 158 jiwa, dan penduduk perempuan sebanyak 167 jiwa dengan jumlah Kepala Keluarga (KK) sebanyak 104. Sedangkan bangunan rumah masyarakat Kampung Naga berjumlah 110 bangunan ditambah dua bangunan khusus, yaitu satu Balai Pertemuan dan satu Masjid sebagai tempat ibadah. Namun, jumlah jiwa masyarakat Kampung Naga yang termasuk adat "Sa Naga" yaitu warga Kampung Naga yang bertempat tinggal di luar Kampung Naga (di luar Desa Neglasari), jumlahnya tentu lebih banyak. Bahkan ada juga warga Kampung Naga yang bertempat tinggal di kota-kota besar seperti Garut, Singaparna, Tasikmalaya, Bandung, Cirebon dan bahkan di Ibukota Jakarta.

Berdasarkan penjelasan Sesepuh Kampung Naga, mereka yang bertempat tinggal di luar Kampung Naga akan tetapi terkait oleh adat Sa Naga maka pada setiap penyelenggaraan upacara adat mereka harus datang ke Kampung Naga untuk berziarah ke makam keramat. Namun bagi mereka yang tinggal diluar, tidak lagi terkait secara khusus oleh ketentuan adat seperti membuat rumah panggung dan aturan-aturan lainnya.

Untuk kelangsungan hidupnya, masyarakat Kampung Naga memiliki sumber mata pencaharian dari pertanian sawah dan perladangan, baik yang statusnya sebagai petani pemilik, petani penggarap, maupun buruh tani. Adapun mata pencaharian tambahan yang dikuasai oleh masyarakat Kampung Naga adalah membuat barang anyaman / kerajinan tangan dari bambu.

Sarana pendidikan yang terdapat di Kampung Naga baik untuk tingkat Sekolah Dasar (SD) maupun untuk tingkat Sekolah Lanjutan Tingkat Pertama (SLTP) belum tersedia. Oleh sebab itu, anak-anak masyarakat Kampung Naga yang ingin mengenyam pendidikan formal harus keluar dari Kampung Naga. Di Sekolah Dasar Negeri Neglasari, jumlah anak-anak sekolah (siswa) asal dari Kampung Naga yang mengenyam pendidikan di sekolah tersebut berjumlah sebanyak 15 orang. Sedangkan jumlah anak asal Kampung Naga yang mengenyam pendidikan di Sekolah Lanjutan Tingkat Pertama di SMP Negeri Salawu sebanyak dua orang.

Penduduk Kampung Naga semuanya mengaku memeluk agama Islam, namun sebagaimana masyarakat adat lainnya, mereka juga sangat taat dalam memegang adat istiadat dan kepercayaan nenek moyangnya. Artinya, walaupun mereka menyatakan 
memeluk agama Islam, namun syariat Islam yang mereka jalani memiliki sedikit perbedaan dengan pemeluk agama Islam pada umumnya. Masyarakat Kampung Naga dalam menjalankan agamanya, mereka juga masih sangat patuh pada warisan nenek moyangnya. Umpamanya sembahyang (sholat) wajib sholat lima waktu hanya dilakukan pada hari jumat, sedangkan pada hari-hari yang lain mereka tidak melaksanakannya. Pengajian bagi orang tua dilaksanakan pada malam Jumat dan pelajaran mengaji bagi anak-anak di Kampung Naga dilaksanakan pada senin dan malam Kamis. Dalam menunaikan Rukun Islam yang kelima yakni ibadah haji, menurut anggapan mereka, tidak perlu jauh-jauh pergi ke Tanah Suci Mekah. Mereka berkeyakinan cukup dengan menjalankan upacara Hajat Sasih yang dilaksanakan bertepatan dengan hari Raya Haji, yakni setiap tanggal 10 Rayagung (Djulhijah). Upacara Hajat saat ini menurut kepercayaan masyarakat Kampung Naga sama dengan Hari Raya Idul Fitri dan Hari Raya Idul Adha.

Menurut kepercayaan masyarakat Kampung Naga, dengan menjalankan adat istiadat warisan nenek moyang, berarti menghormati para leluhur atau Karuhun. Sesuatu yang datangnya bukan dari ajaran Karuhun Kampung Naga, dan sesuatu yang tidak dilakukan karuhunnya dianggap sesuatu yang tabu. Apabila hal-hal tersebut dilakukan oleh masyarakat Kampung Naga, berarti telah melanggar adat, tidak menghormati Karuhun, dan hal ini menurut anggapan mereka pasti akan menimbulkan malapetaka.

Kepercayaan masyarakat Kampung Naga kepada makhluk halus juga masih dipegang kuat. Hal ini terbukti dan banyaknya tempat-tempat yang oleh masyarakat Kampung Naga dianggap sebagai tempat yang angker atau "sanget" seperti tempattempat yang dijadikan tempat sakral seperti makam Sembah Eyang Singaparna, Bumi Ageung, dan masjid yang merupakan tempat yang dipandang suci.

Tabu, pantangan atau pamali bagi masyarakat Kampung Naga masih dilaksanakan dengan patuh, khususnya dalam kehidupan sehari-hari, terutama yang berkaitan dengan aktivitas kehidupannya. Pantangan atau pamali merupakan ketentuan hukum yang tidak tertulis yang mereka junjung tinggi dan dipatuhi oleh setiap orang. Misalnya tatacara dalam membangun rumah, bentuk rumah, letak dan arah rumah, pakaian upacara, kesenian, dan lain sebagainya.

Sistem kemasyarakatan di Kampung Naga tidak lepas dari unsur-unsur adat istiadat leluhur yang sampai sekarang masih tetap dipertahankan dan dipegang teguh oleh masyarakatnya. Tingkat ekonomi seseorang didalam masyarakat Kampung 
Naga tidak pernah menjadi ukuran, dan kekayaan/kepemilikan barang-barang mewah tidak akan menjadikan seseorang naik pada lapisan tertentu. Lapisan sosial yang mendapat pengakuan tinggi dari masyarakat Kampung Naga tidak lain adalah bagaimana seseorang dalam kehidupan sehari-harinya dan kepatuhan pada adat seperti Kuncen, Lebe / Amil, Punduh / Tua Kampung, serta beberapa orang yang dipercaya untuk membantu mengurus tata cara upacara dan melestarikan adat istiadat nenek moyang.

Kuncen adalah kepala adat yang dipilih menurut adat dan berlaku secara turun temurun, dan hanya boleh dijabat oleh seorang laki-laki. Ia merupakan Sesepuh Kampung Adat yang sangat dihormati oleh masyarakat, dan segala ucapannya yang berhubungan dengan adat istiadat selalu dipatuhinya. Menurut anggapan masyarakat Kampung Naga, Kuncen adalah orang yang memiliki kelebihan, baik pengetahuan maupun pengalaman dalam masalah adat. Kuncen dibantu oleh seorang Lebe / Amil dan Punduh / Tua Kampung yang dipilih secara turun temurun berdasarkan keturunan. Tugas Lebe yaitu membantu kuncen dalam bidang keagamaan dan mengurus kematian. Sedangkan Punduh atau Tua Kampung mempunyai tugas sebagai penghubung antara Kuncen dengan masyarakat. Selain itu, yang mendapat pengakuan tinggi dari masyarakat yaitu pejabat pemerintahan (Ketua RW dan Ketua RT yang dipilih secara musyawarah) yang mengurus masalah kehidupan sehari-hari warga dan khususnya yang berhubungan dengan sistem pemerintahan desa. Mereka mendapat tempat yang tinggi di mata masyarakat dan dalam upacara adat mereka juga dipandang sebagai Sesepuh Kampung.

Kampung Naga memiliki dua bentuk sistem kepemimpinan yaitu, kepemimpinan formal dan kepemimpinan non-formal (informal). Kepemimpinan formal adalah kepemimpinan yang dipilih atas dasar pemilihan rakyat dan mendapat legitimasi dari pemerintah. Kepemimpinan formal di Kampung Adat dipegang oleh ketua RW dan ketua RT yang langsung berhubungan dengan sistem pemerintahan. Sedangkan pemimpin informal adalah kepemimpinan yang ditentukan menurut ketentuan adat. Pemimpin adat adalah seseorang yang bisa disebut Kuncen. Sebagai seseorang yang dituakan, perkataan Kuncen sangat didengar dan dipatuhi oleh masyarakat Kampung Adat. Kuncen memiliki hak dalam menerima tamu dan memberi petunjuk-petunjuk khusus dalam kehidupan adat istiadat Kampung Naga.

Peranan Kuncen sebagai pemimpin informal di Kampung Naga terlihat konkrit ketika memberi nasihat, saran dan pendapat tentang bagaimana ia harus 
mengendalikan perilaku masyarakat Kampung Naga. Kepatuhan warga kepada Kuncen karena ia dipandang sebagai pengemban amanat leluhur, sehingga apa yang diucapkannya akan dipatuhi termasuk larangan untuk tidak membicarakan sejarah, asal usul Kampung Naga, serta tradisi pada hari-hari tertentu. Dalam pelaksanaan kehidupan sehari-harinya, kedua pelaksana sistem kepemimpinan di Kampung Adat Naga maupun masyarakat Desa Neglasari berjalan secara beriringan.

Masyarakat yang tinggal di wilayah Kampung Naga maupun warganya yang tinggal di luar wilayah Kampung Naga, masih terkait oleh adat Sa Naga. Mereka dengan kerabatnya yang secara biologis masih terkait pada adat Kampung Naga selalu melakukan kegiatan bersama dan ketentuan tersebut dipatuhi oleh seluruh warga Sa Naga. Pada hakikatnya, berbagai kegiatan dan upacara yang dilaksanakan mampu menyatukan mereka dalam satu ikatan kekeluargaan dan satu keturunan yang demikiat kuatnya.

\section{Karakteristik Individu dan Sosial Kaitannya Kaitannya dengan Pola Pertukaran Informasi}

Dalam masyarakat Kampung Naga, segala ketentuan adat istiadat nenek moyang atau leluhur masih sangat kuat dipertahankan dan dilestarikan secara turun temurun. Hal itu nampak terlihat dalam kehidupan sehari-hari seperti dalam tata cara kehidupan, bentuk rumah, cara bercocok tanam dan bertani, aktifitas berkomunikasi diantara mereka serta dalam cara memandang dan memperlakukan alam dan lingkungan sekitarnya.

Sebagaimana dalam suatu masyarakat, biasanya akan terjadi interaksi antara satu dengan yang lainnya. Dengan adanya interaksi maka akan terjadi komunikasi dan pertukaran informasi diantara sesama anggota masyarakat. Kajian mengenai karakteristik individu masyarakat Kampung Naga dan kaitannya dengan pola pertukaran informasi didalam masyarakat pada penelitian ini difokuskan pada beberapa aspek yang meliputi : pendidikan, jenis kelamin, agama, dan status sosial.

Sarana pendidikan yang terdapat di Kampung Naga sesuai dengan pembahasan sebelumnya dapat dikatakan tidak ada. Sarana pendidikan yang terdekat yakni berada di Desa Neglasari (untuk Sekolah Dasar) dan di Kecamatan Salawu (untuk Sekolah Lanjut Pertama). Itupun jika dikaji lebih jauh lagi, jumlah siswa yang berasal dari masyarakat Kampung Naga yang mengenyam pendidikan dasar dan pendidikan lanjutan tingkat pertama tersebut jumlahnya tidak terlampau signifikan 
jika dibandingkan dengan jumlah penduduk Kampung Naga yang mencapai 325 orang.

Jumlah penduduk masyarakat Kampung Naga yang berjenis kelamin perempuan berjumlah 167 jiwa, sedikit lebih banyak dibandingkan dengan jumlah laki-laki, yakni sebanyak 158 jiwa. Namun dalam kehidupan sosial, perbedaan jumlah penduduk antara yang berjenis kelamin perempuan dan laki-laki ini tidak menjadi permasalahan yang berarti bagi warga masyarakat Kampung Naga. Terkecuali untuk menjabat sebagai Kuncen Kampung Naga yang sesuai adat dan ketentuan yang berlaku harus dan hanya boleh dijabat oleh seorang laki-laki. Kemudian dalam masalah pembagian hak waris, terdapat dua kebiasaan, yakni: (a) sebagian masyarakat yang berpatokan pada hukum atau syariat agama Islam, maka hak waris untuk laki-laki dan perempuan adalah dua berbanding satu; sedangkan bagi (b) sebagian warga lainnya yang teguh mempertahankan adat peninggalan leluhurnya, maka mereka membagi warisan berdasarkan hukum adat yang tidak membedakan hak antara laki-laki dan perempuan, keduanya mendapat hak pembagian harta waris yang sama besarnya.

Penduduk Kampung Naga umumnya memeluk ajaran agama Islam, namun sebagaimana masyarakat adat lainnya, mereka juga sangat taat dalam memegang adat istiadat dan kepercayaan nenek moyangnya. Artinya, walaupun mereka memyatakan memeluk agama Islam, namun syariat Islam yang mereka jalankan agak berbeda dengan pemeluk agama Islam pada umumnya. Selain taat dalam menjalankan agamanya, mereka juga masih sangat taat pada ajaran kepercayaan dari warisan nenek moyangnya. Menurut kepercayaan masyarakat Kampung Naga, dengan menjalankan adat istiadat warisan nenek moyang, berarti menghormati para leluhur atau Karuhun. Sesuatu yang datangnya bukan dari ajaran Karuhun Kampung Naga, dan sesuatu yang tidak dilakukan oleh para leluhurnya maka dianggap sesuatu yang tabu. Apabila hal-hal tersebut dilakukan oleh masyarakat Kampung Naga, berarti telah melanggar adat, tidak menghormati Karuhun, dan hal ini menurut anggapan mereka pasti akan menimbulkan malapetaka.

Dinamika kehidupan dan kemajuan teknologi yang tidak terbendung juga merambah ke masyarakat Kampung Naga. Masyarakat yang semula tertutup kini mulai membuka diri terhadap berbagai informasi dari luar. Sekalipun dalam jumlah terbatas, pesawat televisi dan radio telah hadir cukup lama di Kampung Naga. Akan tetapi kuatnya adat yang mereka dukung telah menangkal pengaruh nilai-nilai baru 
yang tidak sesuai dengan adat istiadat mereka. Sehingga sampai dengan saat ini, dampak negatif akan kehadiran benda-benda tersebut belum nampak secara signifikan.

Tingkat ekonomi seseorang didalam masyarakat Kampung Naga tidak pernah menjadi ukuran, dan kekayaan/kepemilikan barang-barang mewah tidak akan menjadikan seseorang naik pada lapisan/strata sosial tertentu. Lapisan/strata sosial yang mendapat pengakuan tinggi dari masyarakat Kampung Naga tidak lain adalah bagaimana seseorang dalam kehidupan sehari-harinya dan kepatuhan pada adat seperti Kuncen, Lebe / Amil, Punduh / Tua Kampung, serta beberapa orang yang dipercaya untuk membantu mengurus masalah upacara dan adat istiadat. Inilah kesepakatan bersama dan ketentuan dari nenek moyang mereka yang selalu dipatuhi secara turun temurun.

Selain Kuncen, yang mendapat pengakuan tinggi dari masyarakat ialah Pejabat Pemerintah seperti RT dan RW setempat. Mereka adalah sesepuh kampung adat yang sangat dihormati oleh masyarakat, segala ucapannya yang berhubungan dengan adat istiadat selalu dipatuhi. Pejabat Pemerintah dipilih melalui musyawarah masyarakat kampung adat, merekalah yang mengurus masalah kehidupan sehari-hari warga, khususnya yang berhubungan dengan sistem pemerintahan desa. Mereka mendapat tempat yang tinggi dimata masyarakat dan dalam upacara adat mereka dipandang sebagai Sesepuh kampung. Kedudukan (status) dan peranan (role) merupakan unsur-unsur baku dalam sistem lapisan masyarakat, dan mempunyai arti penting bagi sistem sosial. Yang diartikan sebagai sistem sosial adalah pola-pola yang mengatur hubungan timbal-balik antar individu dalam masyarakat dan antara individu dengan masyarakatnya, dan tingkah-laku individu-individu tersebut (Linton dalam Soekanto, 2002 : 239).

Kedudukan diartikan sebagai tempat atau posisi seseorang dalam suatu kelompok sosial. Kedudukan sosial artinya adalah tempat seseorang secara umum dalam masyarakatnya sehubungan dengan orang-orang lain, dalam arti lingkungan pergaulannya, prestise-nya dan hak-hak serta kewajiban-kewajibannya. Menurut Linton dalam Soekanto (2002 : 239), secara abstrak, kedudukan berarti tempat seseorang dalam suatu pola tertentu. Dijelaskan lebih lanjut, bahwa seseorang dikatakan mempunyai beberapa kedudukan, oleh karena seseorang biasanya ikut serta dalam berbagai pola kehidupan. Pengertian tersebut menunjukkan tempatnya sehubungan dengan kerangka masyarakat secara menyeluruh. 
Pembahasan berikutnya yakni tentang karakteristik sosial yang berupa normanorma sosial yang ada pada masyarakat Kampung Naga dan kaitannya dengan pola pertukaran informasi dikalangan masyarakat disana. Norma-norma dalam suatu masyarakat dirumuskan agar supaya hubungan antara manusia didalam suatu masyarakat terlaksana sebagaimana yang diharapkan. Norma-norma yang ada dalam masyarakat, mempunyai kekuatan mengikat yang berbeda-beda. Ada norma yang lemah, yang sedang sampai yang terkuat daya ikatnya. Pada norma yang paling kuat daya ikatnya, umumnya anggota-anggota masyarakat tidak berani melanggarnya. Norma-norma tersebut, setelah mengalami suatu proses pada akhirnya menjadi bagian tertentu (melembaga) dalam suatu lingkungan masyarakat. Proses tersebut dinamakan proses pelembagaan (institutionalization), yaitu suatu proses yang dilewatkan oleh suatu norma yang baru untuk menjadi bagian dari salah satu lembaga kemasyarakatan. Yang dimaksud disini adalah hingga norma itu oleh masyarakat dikenal, dihargai dan kemudian ditaati dalam kehidupan sehari-hari (Wiese dan Becker dalam Soekanto, 2002 : 203).

Norma-norma yang masih kuat dipertahankan sampai dengan saat ini oleh masyarakat Kampung Naga yakni berupa segala adat istiadat nenek moyang atau leluhur mereka. Hal ini terlihat dalam kehidupan sehari-hari mereka seperti dalam taat kehidupannya, bentuk rumah, cara bercocok tanam/bertani, kegiatan berkomunikasi diantara mereka, serta dalam cara memandang dan memperlakukan alam dan lingkungan sekitarnya. Penduduk Kampung Naga sangat taat dalam memegang adat istiadat dan kepercayaan nenek moyangnya, seperti dalam hal menjalankan perintah agama (Islam), bentuk rumah yang harus panggung, bahan dari bambu dan kayu, atap rumah harus dari daun nipah, ijuk atau alang-alang, serta lantai rumah harus dari bambu atau papan kayu.

Rumah juga tidak boleh dilengkapi dengan perabotan. Dalam bidang kesenian pun diatur dengan ketentuan adat. Begitu pula dengan pantangan atau tabu, kepercayaan terhadap ruang dan waktu, dalam sistem kemasyarakatan (terutama dalam pelapisan sosial, kepemimpinan dan kekerabatan), pola pemukiman serta upacara adat. Sehingga dapat dikatakan bawah berbagai karakteristik sosial yang ada, memberikan pengaruh yang cukup besar terhadap pola pertukaran informasi diantara masyarakat disana. Meskipun teknologi komunikasi (media massa) sudah masuk kedalam lingkungan masyarakat adat, namun tidak serta merta mempengaruhi kehidupan disana. Masyarakat jauh lebih percaya kepada informasi yang 
disampaikan Kuncen atau Sesepuh daripada dari sumber lain yang mereka anggap belum tentu kebenarannya. Apalagi jika informasi tersebut bertentangan dengan nilai dan norma yang mereka yakini sesuai ajaran agama maupun ajaran leluhur. Dalam hal ini peran Kuncen maupun Sesepuh sangat besar sebagai sumber informasi bagi kehidupan mereka.

\section{SIMPULAN DAN SARAN}

Penelitian ini memperoleh suatu simpulan bahwa karakteristik individu yang meliputi pendidikan, jenis kelamin, serta agama tidak begitu mempengaruhi polapola pertukaran informasi diantara masyarakat Kampung Naga. Hal tersebut dikarenakan masyarakat disana masih berpegang teguh pada adat istiadat yang diwariskan oleh leluhurnya yang direpresentasikan melalui nasihat, saran dan pendapat pemimpin adat (kuncen) dalam mempertahankan adat istiadat setempat.

Karakteristik sosial berupa norma-norma sosial yang masih dipegang erat hingga saat ini turut memperlancar pola pertukaran informasi dikalangan masyarakat. Kepatuhan warga kepada Kuncen, sebagai pengemban amanat leluhur masyarakat Kampung Naga, juga turut mempermudah pola pertukaran informasi antara masyarakat Kampung Naga. Hal tersebut dapat dilihat ketika Kuncen memberi nasihat, saran dan pendapat dalam mempertahankan adat istiadat setempat.

Adapun saran dari hasil penelitian ini yakni diperlukan suatu kajian lebih mendalam dan menyeluruh tentang karakteristik individu pada masyarakat Kampung Naga dalam kaitannya dengan pola pertukaran informasi dilihat dari berbagai aspek demografi lainnya. Selain itu, karakteristik sosial yang berupa norma-norma sosial yang masih dipegang erat sampai saat ini oleh masyarakat Kampung Naga perlu terus dipertahankan dan dibina. Kepatuhan warga kepada Kuncen yang mempermudah pola pertukaran informasi antara masyarakat Kampung Naga juga perlu dipertahankan karena pada nantinya akan mempermudah proses komunikasi antar warga masyarakat serta antar warga masyarakat dengan masyarakat lainnya.

\section{DAFTAR PUSTAKA}

Diao, A.L. 1996. Metode Penelitian Kualitatif dalam Penelitian tentang Kebutuhan dan Perilaku Pemakai Informasi, dalam Prosiding Seminar Sehari Layanan Pusdokinfo Berorientasi Pemakai di Era Informasi : Pandangan Akademisi dan Praktisi, Depok : Universitas Indonesia.

Effendy, Onong Uchjana. 2006. Ilmu Komunikasi : Teori dan Praktek, Bandung : Remaja Rosda Karya. 
Hanafi, Abdillah. 1999. Memahami Komunikasi Antar Manusia, Surabaya : Usaha Nasional.

Liliweri, Alo. 1994. Komunikasi Verbal dan Non-Verbal, Bandung : Citra Aditya Bakti.

Singarimbun, Masri dan Sofian Effendi. 1989. Metode Penelitian Survai, Jakarta ; LPSE.

Mulyana, Dedi. 2000. Ilmu Komunikasi : Suatu Pengantar, Bandung : Remaja Rosda Karya.

Rakhmat, Jalaluddin. 2003. Psikologi Komunikasi, Bandung : Remaja Rosda Karya.

Soekanto, Soejono. 2002. Sosiologi Suatu Pengantar. Jakarta : Raja Grafindo Persida.

Tubbs, Stewart L dan Sylvia Moss. 1996. Human Communication : Prinsip-prinsip Dasar (terjemahan), Bandung : Remaja Rosda Karya. 